\title{
Cytometry Part A Journal
}

Copy of e-mail Notification

Cytometry Part A Published by Wiley Periodicals, Inc.

Dear Author,

Please refer to this URL address http://115.111.50.156/jw/retrieval.aspx?pwd=1f363365dbfe

Login: your e-mail address; Password:1f363365dbfe

The site contains 1 file. You will need to have Adobe Acrobat $\circledast$ Reader software to read these files. This is free software and is available for user downloading at http://www.adobe.com/products/acrobat/readstep.html.

This file contains: 1) Author Instructions Checklist 2)Adobe Acrobat Users - NOTES tool sheet; 3) Reprint Order Information; 4) Copyright Transfer Agreement; 5) An ISAC membership form \& letter Announcement; 6) A copy of your page proofs for your article

After printing the PDF file, please read the page proofs carefully and:

1 ) indicate changes or corrections in the margin of the page proofs; 2) answer all queries (footnotes A,B,C, etc.) on the last page of the PDF proof; 3) proofread any tables and equations carefully; 4) check that any Greek, especially $\mu$ (mu), has translated correctly.

Within 48 hours, please return the following to the address given below:

1) Corrected page proofs; 2) TIFF or EPS files of figures for correction (if necessary);

(NOTE: articles cannot be published without a copyright form signed by all authors.)

If you have any problems or questions, please contact Balaji/Sam (e-mail: Wiley.CS@cenveo.com, phone: +91 (44) 4205-8810 (ext.308)). or the production editor L. Graup at the address shown below. PLEASE ALWAYS INCLUDE YOUR ARTICLE NO. ( 22583 ) WITH ALL CORRESPONDENCE.

This e-proof is to be used only for the purpose of returning corrections to the publisher.

Sincerely,

Larry Graup

Wiley-Blackwell Production

610 Bear Creek St, Auburn,PA 17922 USA

Phone: 570-754-3060;FAX: 570-754-2247

E-mail: Igraup@infionline.net 


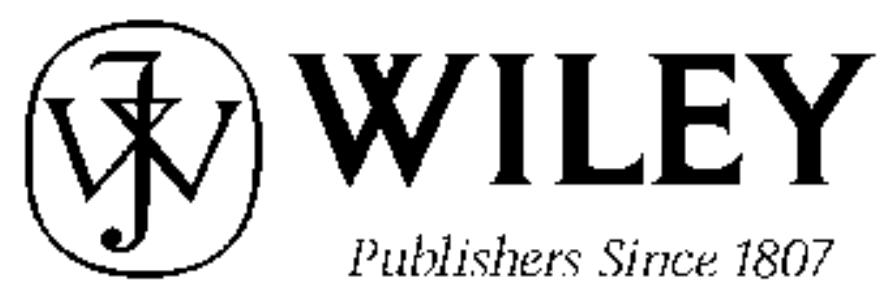

111 River StReEt, HObOKEN, NJ 07030

***IMMEDIATE RESPONSE REQUIRED***

Your article will be published online via Wiley's EarlyView service (wileyonlinelibrary.com) shortly after receipt of corrections. EarlyView is Wiley's online publication of individual articles in full-text HTML, and/or pdf format before release of the compiled print issue of the journal. Articles posted online in EarlyView are peer-reviewed, copyedited, author corrected, and fully citable. EarlyView means you benefit from the best of two worlds - fast online availability as well as traditional, issue-based archiving.

\title{
READ PROOFS CAREFULLY
}

- This will be your only chance to review these proofs.

- $\quad$ Please note that the volume and page numbers shown on the proofs are for position only.

ANSWER ALL QUERIES ON PROOFS (Queries for you to answer are attached as the last page of your proof.)

- Please mark all corrections clearly. Note that excessive author alterations may ultimately result in delay of publication and extra costs may be charged to you.

\section{CHECK FIGURES AND TABLES CAREFULLY}

- $\quad$ Check size, numbering, and orientation of figures.

- All images in the PDF are downsampled (reduced to lower resolution and file size) to facilitate Internet delivery. These images will appear at higher resolution and sharpness in the printed article.

- Review figure legends to ensure that they are complete.

- Check all tables. Review layout, title, and footnotes.

\section{ADDITIONAL COPIES}

- If you wish to purchase additional copies of the journal in which your article appears, please contact cs-journals@wiley.com

$\begin{array}{ll}\text { RETURN } & \square \text { PROOF } \\ & \square \text { CTA (If you have not already submitted one) }\end{array}$

Send the corrected proof's pdf file by email attachment (or scan, or fax or express mail the proof) to:

\author{
Larry Graup, \\ Wiley-Blackwell Journal Production \\ 610 Bear Creek Street, \\ Auburn, PA 17922 USA \\ E-mail: Igraup@infionline.net \\ Fax: 570-754-2247 \\ Phone: 570-754-3060
}

RETURN IMMEDIATELY AS YOUR ARTICLE WILL BE POSTED IN ORDER OF RECEIPT. YOU CAN EXPECT TO SEE YOUR ARTICLE ONLINE SHORTLY AFTER RECEIPT OF CORRECTIONS. 


\section{(WILEY-BLACKWELL}

\section{Additional reprint purchases}

Should you wish to purchase additional copies of your article, please click on the link and follow the instructions provided:

https://caesar.sheridan.com/reprints/redir.php?pub=10089\&acro=CYTOA

Corresponding authors are invited to inform their co-authors of the reprint options available.

Please note that regardless of the form in which they are acquired, reprints should not be resold, nor further disseminated in electronic form, nor deployed in part or in whole in any marketing, promotional or educational contexts without authorization from Wiley. Permissions requests should be directed to mail to: permissionsus@wiley.com

For information about 'Pay-Per-View and Article Select' click on the following link: wileyonlinelibrary.com/aboutus/ppv-articleselect.html 
Required software to e-Annotate PDFs: Adobe Acrobat Professional or Adobe Reader (version 8.0 or above). (Note that this document uses screenshots from Adobe Reader $\mathrm{X}$ )

The latest version of Acrobat Reader can be downloaded for free at: http://get.adobe.com/readerl

Once you have Acrobat Reader open on your computer, click on the Comment tab at the right of the toolbar:

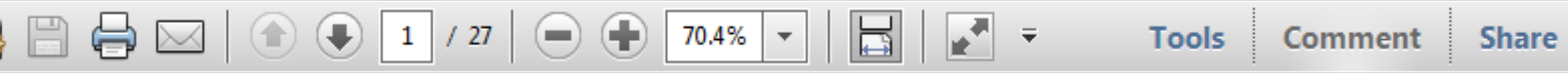

This will open up a panel down the right side of the document. The majority of tools you will use for annotating your proof will be in the Annotations section, pictured opposite. We've picked out some of these tools below:

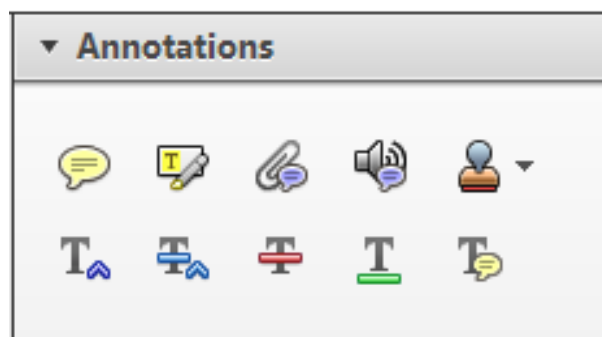

1. Replace (Ins) Tool - for replacing text.

T Strikes a line through text and opens up a text box where replacement text can be entered.

\section{How to use it}

- Highlight a word or sentence.

- Click on the Replace (Ins) icon in the Annotations section.

- Type the replacement text into the blue box that appears.

Idard tramework for the analysis of $\mathrm{m}$ icy Nevertheless, it also led to exog، sle of strateg aber of comp 08/06/2011 15:58:17 is that the $\mathrm { s } 1 \longdiv { \text { ,wich led } }$ of nain compo: be level, are exc nc

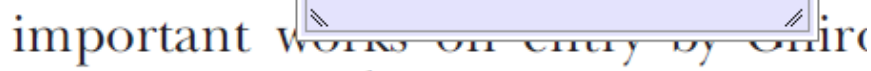
M heneferth) ${ }^{1}$ we anen the 'hlark $\mathrm{h}$

3. Add note to text Tool - for highlighting a section to be changed to bold or italic.

Tighlights text in yellow and opens up a text box where comments can be entered.

\section{How to use it}

- Highlight the relevant section of text.

- Click on the Add note to text icon in the Annotations section.

- Type instruction on what should be changed regarding the text into the yellow box that annears

namic responses of mark ups ent with the VAR evidence

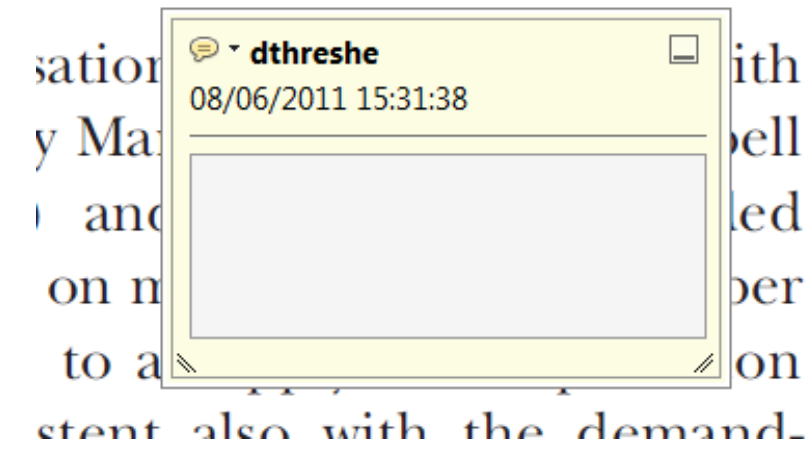

2. Strikethrough (Del) Tool - for deleting text.

Strikes a red line through text that is to be deleted.

How to use it

- Highlight a word or sentence.

- Click on the Strikethrough (Del) icon in the Annotations section.

there is no room tor extra prohts al s ups are zero and the number of ret) values are not determined by Blanchard and Kiyotaki (1987), rfect competition in general equilil ts of aggregate demand and supply lassical framework assuming monol eon an evorenois number of firms

4. Add sticky note Tool - for making notes at specific points in the text.

Marks a point in the proof where a comment needs to be highlighted.

\section{How to use it}

- Click on the Add sticky note icon in the Annotations section.

- Click at the point in the proof where the comment should be inserted.

- Type the comment into the yellow box that appears.

lailu ailu suppiy silucks. Iviusl ul

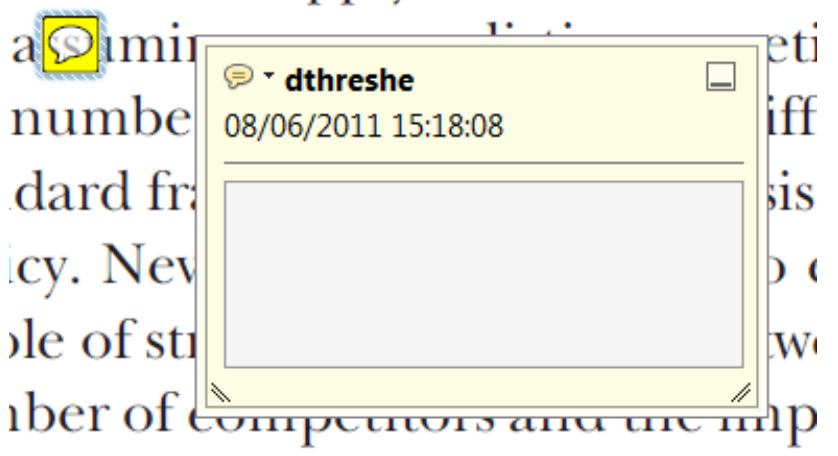
is that the structure of the secto 
5. Attach File Tool - for inserting large amounts of text or replacement figures.

Inserts an icon linking to the attached file in the appropriate pace in the text.

How to use it

- Click on the Attach File icon in the Annotations section.

- Click on the proof to where you'd like the attached file to be linked.

- Select the file to be attached from your computer or network.

- Select the colour and type of icon that will appear in the proof. Click OK.

E N D

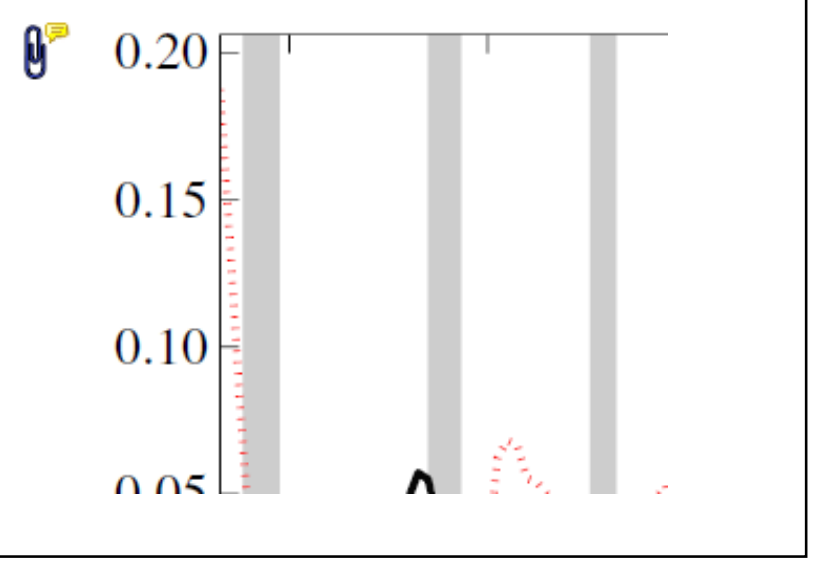

6. Add stamp Tool - for approving a proof if no corrections are required.

- Inserts a selected stamp onto an appropriate place in the proof

\section{How to use it}

- $\quad$ Click on the Add stamp icon in the Annotations section.

- Select the stamp you want to use. (The Approved stamp is usually available directly in the menu that appears).

- Click on the proof where you'd like the stamp to appear. (Where a proof is to be approved as it is, this would normally be on the first page).

It the Dusiness cycie, starting with the on perfect competition, constant ret

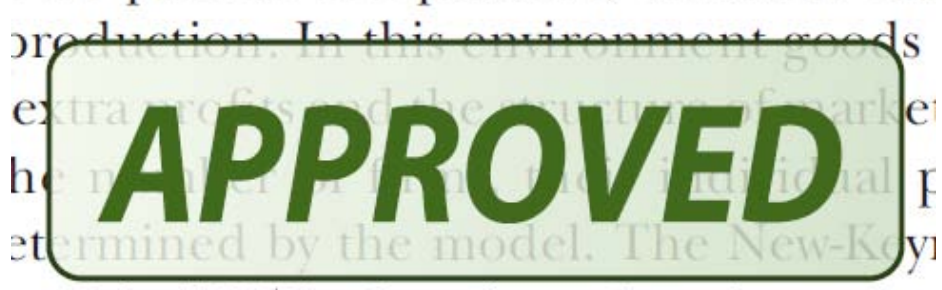

otaki (1987), has introduced produc general equilibrium models with nomin
- Drawing Markups

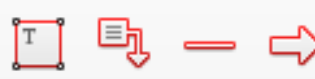

$0 \square \sqrt{6} D$

\section{How to use it}

- Click on one of the shapes in the Drawing Markups section.

- Click on the proof at the relevant point and draw the selected shape with the cursor.

- To add a comment to the drawn shape, move the cursor over the shape until an arrowhead appears.

- Double click on the shape and type any text in the red box that appears.
7. Drawing Markups Tools - for drawing shapes, lines and freeform annotations on proofs and commenting on these marks.

Allows shapes, lines and freeform annotations to be drawn on proofs and for comment to be made on these marks..

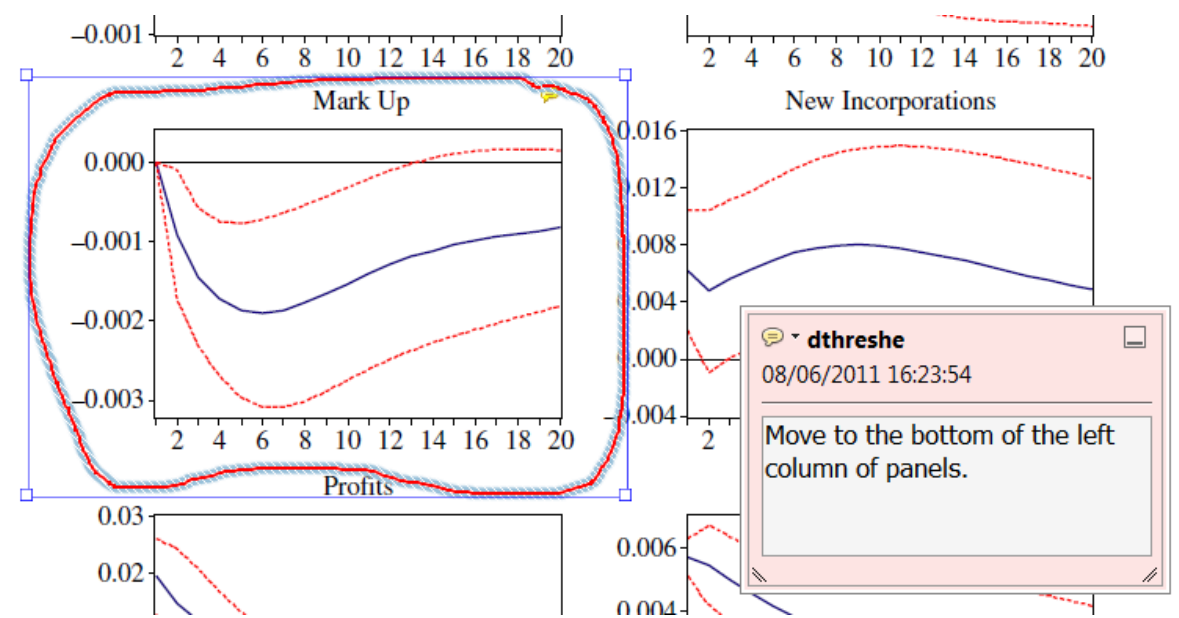

For further information on how to annotate proofs, click on the Help menu to reveal a list of further options:

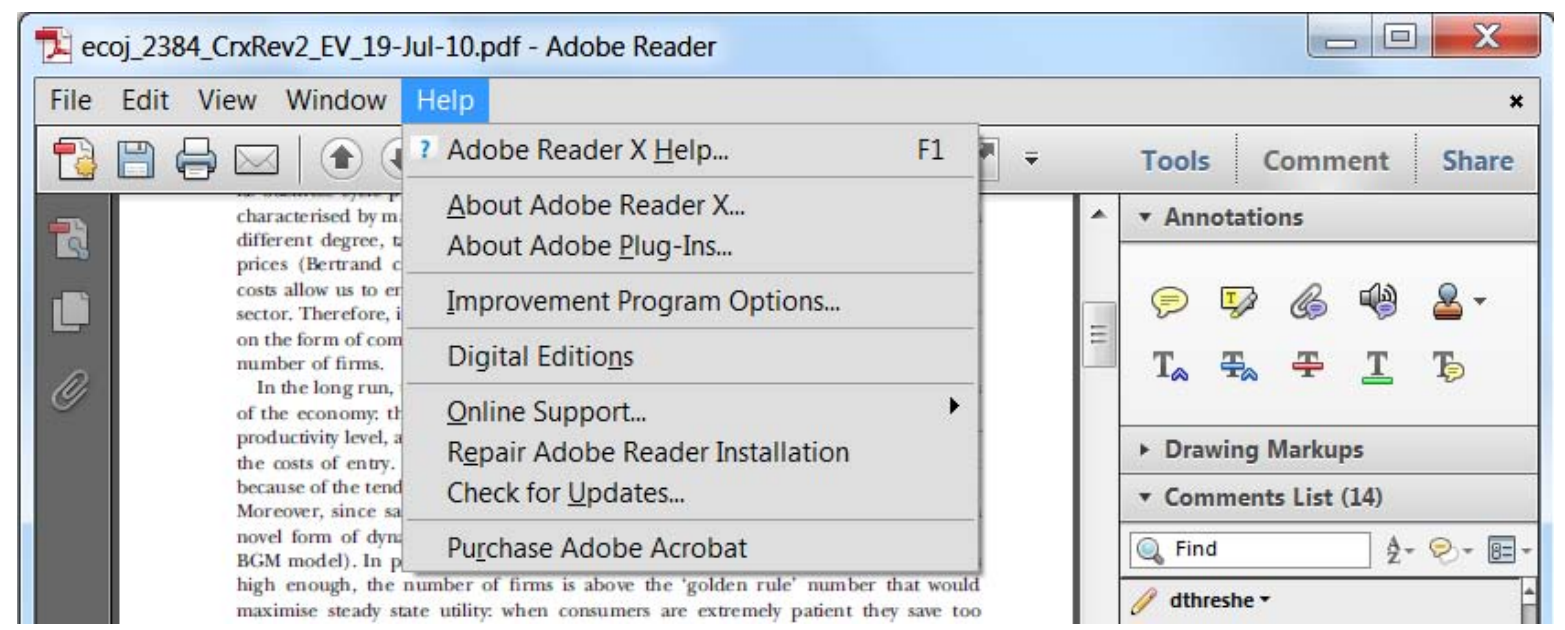




\section{ISAC MEMBERSHIP APPLICATION}

L

Please include current telephone number, fax and e-mail address on back of form. Make any address changes on back of form.

\section{Membership Dues for Calendar Year 2014}

You can join ISAC online at www.isac-net.org. To ensure proper crediting of dues and processing of journals please remit dues promptly. Options below include Cytometry Part A. Individual subscriptions to the journals are for personal or laboratory use only and not for institutional use. Please note that if you join after October 1, 2014, subscriptions will not begin until January 2015.

Full Member with print and electronic journal access

$\$ 126$ (or see sliding country scale on reverse page) \$

Three-year membership

Full Member with electronic journal access only $\$ 378$ (or 3 times the reduced sliding scale rate) \$

Three-year membership $\$ 100$ (or see sliding country scale on reverse page) \$

$\$ 300$ (or 3 times the reduced sliding scale rate) \$

\section{Additional Memberships \& Subscriptions}

Renewing International Clinical Cytometry Society (ISSC) members will receive a renewal notice directly from ICCS; do not renew your ICCS membership through ISAC. Individual subscriptions to the journals are for personal or laboratory use only and not for institutional use.

Membership in ICCS: Incl. 6 print issues \& e-access to Cytometry Part B: Clinical Cytometry $\$ 95.00 \$$

Electronic Membership in ICCS Electronic access only to Cytometry Part B: Clinical Cytometry $\$ 75.00 \$$

The options below are available only with ISAC Membership:

ISAC members receive a $20 \%$ discount on an individual online subscription to Current Protocols in Cytometry. Please contact protocol@wiley.com and mention code ISAC3 in the subject line, or call 800-825-7550 (USA) or 1-317-572-3983 (outside the USA).

Subscription to Cytometry Part B: Clinical Cytometry. Includes six print issues and online access.

Subscription to Cytometry Part B: Clinical Cytometry. Online access only. $\$ 64.00 \$$

The ISAC Cytometry CLIA Compliance Manual. Print version; online access is free.

$\$ 50.00 \$$

\section{Payment Options}

Return this invoice with payment in the form of credit card, check or money order. All subscriptions and renewals must be paid in U.S. funds. Checks or money orders must be drawn on a U.S. Bank with the MICR encoded number on the bottom of the check. Make checks payable to: ISAC or International Society for Advancement of Cytometry. Purchase orders, stamps or coupons are NOT accepted as a form of payment. Membership dues to ISAC cannot be deducted as charitable contributions, but may be deductible for federal income tax purposes as ordinary and necessary business expenses. Consult your tax advisor for individual assistance in specific situations. ISAC Federal Tax ID: 85-0319221.

Total Amount from Above (Dues, Donations, Memberships and Subscriptions) $\$$

Bank/Wire Transfers (Contact ISAC for bank transfer information. Name or member ID\# must appear on transfer. All originating bank fees must be pre-paid.) Originating Bank Date of Transfer

Bank Wire Transfer Add handling fee of $\$ 25.00$

Maryland or District of Columbia Residents: Please add 6\% sales tax or provide Tax Exempt Number Canadian Subscriptions: GST of $5 \%$ must be added to total payment. Please include the GST number if available. The price for Canada, Mexico and other international subscriptions includes postage.

\begin{tabular}{|c|c|c|}
\hline \multicolumn{2}{|c|}{ Add handling fee of $\$ 25.00$} & $\$$ \\
\hline & & $\$$ \\
\hline & GST Number & $\$$ \\
\hline & & $\$$ \\
\hline$\square$ VISA & $\square$ Master Card & $\square$ Discover \\
\hline
\end{tabular}

Total Payment Enclosed

Credit Card Information Credit card orders may be faxed to: 301-634-7099

Card Number

Expiration Date

Authorized Signature

\section{American Express}

Name on Card

3 or 4 Digit CVV\# 


\begin{tabular}{|c|c|c|c|c|}
\hline Degree & Field of Study & Research Areas & & Interest Groups \\
\hline$\square$ Ph.D. & $\square$ Biological Sciences & $\square$ Biochemistry & $\square$ Genetics & Check to be associated with one or more \\
\hline$\square$ M.D. & $\square$ Chemical Sciences & $\square$ Biophysics & $\square$ Immunology & of the following groups: \\
\hline$\square$ M.A. & $\square$ Computer Sciences & $\square$ Biotechnology & $\square$ Instrumental Development & $\square$ Biological Cytometry Group \\
\hline$\square$ M.S. & $\square$ Engineering & $\square$ Cell \& Molecular Biology & $\square$ Microbiology & $\square$ Clinical Cytometry Group \\
\hline$\square$ B.A. & $\square$ Medicine & $\square$ Cell Physiology & $\square$ Pathology & $\square$ Cytometric Technology Group \\
\hline$\square$ B.S. & $\square$ Physical Sciences & $\square$ Clinical Lab Practice & $\square$ Plant Biology & $\square$ Core Managers \\
\hline$\square$ Associate & $\square$ Other & $\square$ Clinical Research & $\square$ Other & $\square$ Microparticles \\
\hline$\square$ Other & & $\square$ Flow \& Image Cytometry & & $\square$ Stem Cells \\
\hline
\end{tabular}

Please indicate if there is a particular interest group you would like to see:

interest group you would like to see:

To serve you better with more targeted information and programs, please answer the following new ISAC demographic questions:

What is your institutional setting?

$\begin{array}{ll}\square \text { University } & \square \text { Biotechnology Company } \\ \square \text { Medical School } & \square \text { Testing Laboratory } \\ \square \text { Hospital } & \square \text { Non-Profit } \\ \square \text { Out-Patient Clinic } & \square \text { Government } \\ \square \text { Pharmaceutical Company } & \square \text { Other }\end{array}$

What is your title/job description?

$\square$ Professor/Principal/Investigator
$\square$ Post-doc
$\square$ Core Facility Manager
$\square$ Core Facility Tech
$\square$ Graduate Student
$\square$ Undergraduate Student

$\square$ vP

$\square$ Director

$\square$ Senior Scientist

$\square$ Scientist

$\square$ Technician

$\square$ Physician (Resident/Sr. Resident/Attending)

\section{Contact Information \& Address Changes}

Please provide the following information for changes only:

Phone:

FAX

Name:

Email:

City:

State/Province:

Zip/Postal Code:

2014 ISAC Member Dues Sliding Country Rates

Residents of the following countries pay the full rate. Full membership with print and electronic journal access pays $\$ 126$ for one year or $\$ 378$ for three years. Full membership with electronic journal access only pays $\$ 100$ for one year or $\$ 300$ for three years.

\begin{tabular}{|c|c|c|c|c|c|c|}
\hline Andorra & Canada & Faeroe Islands & Isle of Man & Malta & Qatar & Sweden \\
\hline Antigua \& Barbuda & Cayman Islands & Finland & Israel & Monaco & Russian Federation & Switzerland \\
\hline Aruba & Channel Islands & France & Italy & Netherlands & San Marino & Taiwan \\
\hline Australia & Chile & French Polynesia & Japan & New Caledonia & Saudi Arabia & Trinidad and Tobago \\
\hline Austria & Croatia & Germany & Korea, Rep. & New Zealand & Singapore & Turks and Caicos Islands \\
\hline Bahamas, The & Curacao & Greece & Kuwait & N. Mariana Islands & Sint Maarten & United Arab Emirates \\
\hline Bahrain & Cyprus & Greenland & Latvia & Norway & Slovak Republic & United Kingdom \\
\hline Barbados & Czech Republic & Guam & Liechtenstein & Oman & Slovenia & United States \\
\hline Belgium & Denmark & Hong Kong SAR, China & Lithuania & Poland & Spain & Uruguay \\
\hline Bermuda & Estonia & Iceland & Luxembourg & Portugal & St. Kitts and Nevis & Virgin Islands (U.S.) \\
\hline Brunei Darussalam & Equatorial Guinea & Ireland & Macao SAR, China & Puerto Rico & St. Martin & \\
\hline
\end{tabular}

Residents of the following countries pay $\$ 110$ for one year or $\$ 330$ for three years for full membership with print and electronic journal access.

Full membership with electronic journal access only pays \$84 per year or \$252 for three years.

\begin{tabular}{|c|c|c|c|c|c|c|}
\hline Albania & Bosnia \& Herzegovina & Dominica & Iraq & Maldives & Peru & Thailand \\
\hline Algeria & Botswana & Dominican Republic & Jamaica & Marshall Islands & Romania & Tonga \\
\hline American Samoa & Brazil & Ecuador & Jordan & Mauritius & Serbia & Tunisia \\
\hline Angola & Bulgaria & Fiji & Kazakhstan & Mexico & Seychelles & Turkey \\
\hline Argentina & China & Gabon & Lebanon & Montenegro & South Africa & Turkmenistan \\
\hline Azerbaijan & Colombia & Grenada & Libya & Namibia & St. Lucia & Tuvalu \\
\hline Belarus & Costa Rica & Hungary & Macedonia, FYR & Palau & St. Vincent/Grenadines & Venezuela, RB \\
\hline Belize & Cuba & Iran, Islamic Rep. & Malaysia & Panama & Suriname & \\
\hline
\end{tabular}

Residents of the following countries pay $\$ 94$ for one year or $\$ 282$ for three years for full membership with print and electronic journal access.

\begin{tabular}{|c|c|c|c|c|c|c|}
\hline \multirow[b]{2}{*}{ Armenia } & \multicolumn{5}{|c|}{ Full membership with electronic journal access only pays $\$ 68$ for one year or $\$ 204$ for three years. } & \multirow[b]{2}{*}{ Uzbekistan } \\
\hline & Djibouti & Honduras & Mauritania & Pakistan & Solomon Islands & \\
\hline Bhutan & Egypt, Arab Rep. & Indonesia & Micronesia, Fed. Sts. & Papua New Guinea & Sri Lanka & Vanuatu \\
\hline Bolivia & El Salvador & India & Moldova & Paraguay & Sudan & Vietnam \\
\hline Cameroon & Georgia & Kiribati & Mongolia & Philippines & Swaziland & West Bank and Gaza \\
\hline Cape Verde & Ghana & Kosovo & Morocco & Samoa & Syrian Arab Republic & Yemen, Rep \\
\hline Congo, Rep. & Guatemala & Lao PDR & Nicaragua & Sao Tome \& Principe & Timor-Leste & Zambia \\
\hline Cote d'Ivoire & Guyana & Lesotho & Nigeria & Senegal & Ukraine & \\
\hline
\end{tabular}

Residents of the following countries pay $\$ 78$ for one year or $\$ 234$ for three years for full membership with print and electronic journal access.

\begin{tabular}{|c|c|c|c|c|c|c|}
\hline \\
\hline Afghanistan & Cambodia & Eritrea & Haiti & Madagascar & Nepal & South Sudan \\
\hline Bangladesh & Central African Republic & Ethiopia & Kenya & Malawi & Niger & Tajikistan \\
\hline Benin & Chad & Gambia, The & Korea, Dem. Rep. & Mali & Rwanda & Tanzania \\
\hline Burkina Faso & Comoros & Guinea & Kyrgyz Republic & Mozambique & Sierra Leone & Togo \\
\hline Burundi & Congo, Dem. Rep. & Guinea-Bissau & Liberia & Myanmar & Somalia & $\begin{array}{l}\text { Uganda } \\
\text { Zimbabwe }\end{array}$ \\
\hline
\end{tabular}




\section{Dear Cytometry Contributor:}

Thank you for publishing in Cytometry. Because you recognize the value and importance of this journal as a venue for publishing your work, we invite you to join the International Society for Advancement of Cytometry (ISAC).

One of the many benefits of membership in this esteemed society is that ISAC members now receive a $50 \%$ discount on reprint orders for Cytometry. Membership also guarantees that you will receive this publication at an astonishingly low price!

With Cytometry, you will get unmatched coverage of cytometric and bioimaging techniques in basic and applied biomedical research. The journal embraces all aspects of analytical cytology - from molecular biology, through cytochemistry, cytophysics and cell biology - pathology and physiology to statistics and instrumentation. Clinical Cytometry, the bimonthly section of Cytometry, reports on the use of flow and image cytometry in a clinical setting and is available for a nominal addition to your regular ISAC membership fee.

In fact, we feel that many of your colleagues could benefit from Cytometry's in-depth scientific coverage and desktop delivery of valuable data but they might not be ISAC members. Accessing the journal could be problematic for non-ISAC members if your library does not subscribe. Now you can help ensure that your colleagues have all the latest information they need to conduct their research thoroughly and effectively. Just make sure your library has Cytometry and with it, Clinical Cytometry (a total of 18 issues per year) on the shelves and on-line. For more information, direct your librarians to www.wiley.com/cytometry, or call 1-800-879-4539.

If your library subscribes to Cytometry, you and your colleagues can now browse the full text of each issue on-line. Full text on-line gives you faster, desktop accessing of research findings, flexible search capabilities, and fully downloadable information. To learn more about how to get your library registered, please visit Wiley Online Library (www.wileyonlinelibrary.com) This Internet tool makes Cytometry a more cutting-edge resource than ever before.

Regards, John Wiley \& Sons, Inc. 

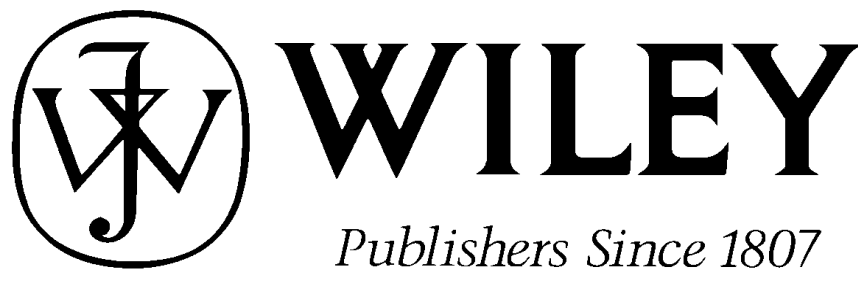

Publishers Since 1807

111 RIVER STREET, HOBOKEN, NJ 07030

ANNOUNCEMENT

NEW TO CYTOMETRY AND CLINICAL CYTOMETRY

\section{Online Submission and Peer Review}

In taking a step toward facilitating online collaboration and expediting the publication process, CYTOMETRY and CLINICAL CYTOMETRY are pleased to now offer web-based submission and peer review. The online submission site offers new functionality not offered before, including:

- Instant confirmation of manuscript receipt

- The ability to track a manuscript's progress through the peer review process

- The ability to submit manuscripts $24 / 7$ from anywhere in the world, via web access

\section{We invite authors to visit the online submission site at http://cyto-wiley.manuscriptcentral.com/.}

\section{To submit manuscript online, please:}

1. Prepare your manuscript and illustrations in appropriate format, according to the instructions given at http://cyto-wiley.manuscriptcentral.com/ under the "Instructions and Forms" button. Please also be sure that your paper conforms to the scientific and style instructions of the Journal.

2. If you have not already done so, create an account for yourself in the system at the submission site: http://cyto-wiley.manuscriptcentral.com/ by clicking on the "Create an Account" button. To monitor the progress of your manuscript through the review process, just login periodically and check your Author Center.

3. Please be sure to study the Instructions and Forms at the site carefully, and then let the system guide you through the submission process. Online help is available to you at all times during the process. You are also able to exit/re-enter at any stage before finally "submitting" your manuscript. All submissions are kept strictly confidential. If you have any questions, do not hesitate to contact us at edsupport@wiley.com 


\section{(3)WILEY-BLACKWELL}

\section{Color reproduction in your Cytometry Part $A$ article}

Color figures were included with the final manuscript that we received for your article.

Due to the high cost of color printing, we can only print figures in color if authors cover the expense.

Color printing costs $\$ 500$. per page regardless of the number of color figures on a page.

Please indicate if you would like your figures to be printed in color or black and white. Color images will be reproduced online in WileyOnlineLibrary at no charge, whether or not you opt for color printing

Failure to return this form will result in publication of your figures in black and white.

Journal : CYTOMETRY PART A Volume: Issue:

Title of Manuscript:

Manus number:

Author(s):

Number of color pages:

\begin{tabular}{|c|c|c|c|}
\hline Number of color pages & Color charges & Number of color pages & Color charges \\
\hline 1 & $\mathbf{5 0 0}$ & $\mathbf{6}$ & $\mathbf{3 0 0 0}$ \\
\hline $\mathbf{2}$ & 1000 & $\mathbf{7}$ & $\mathbf{3 5 0 0}$ \\
\hline $\mathbf{3}$ & 1500 & $\mathbf{8}$ & $\mathbf{4 0 0 0}$ \\
\hline $\mathbf{5}$ & $\mathbf{2 0 0 0}$ & $\mathbf{9}$ & $\mathbf{4 5 0 0}$ \\
\hline
\end{tabular}

Please contact the production editor if you have more than 10 pages of color.

Please print my figures in black and white

Please print my figures in color: $\quad$ Total $\mathbf{\$}$

International orders must be paid in currency and drawn on a U.S. bank

Bill to:

Name

Address

Fax:

Email:

Phone: 
Date:

Contributor name:

Contributor address:

Manuscript number (Editorial office only):

Re: Manuscript entitled

(the "Contribution")

for publication in (the "Journal")

published by ("Wiley-Blackwell").

Dear Contributor(s):

Thank you for submitting your Contribution for publication. In order to expedite the editing and publishing process and enable Wiley-Blackwell to disseminate your Contribution to the fullest extent, we need to have this Copyright Transfer Agreement signed and returned as directed in the Journal's instructions for authors as soon as possible. If the Contribution is not accepted for publication, or if the Contribution is subsequently rejected, this Agreement shall be null and void. Publication cannot proceed without a signed copy of this Agreement.

\section{A. COPYRIGHT}

1. The Contributor assigns to Wiley-Blackwell, during the full term of copyright and any extensions or renewals, all copyright in and to the Contribution, and all rights therein, including but not limited to the right to publish, republish, transmit, sell, distribute and otherwise use the Contribution in whole or in part in electronic and print editions of the Journal and in derivative works throughout the world, in all languages and in all media of expression now known or later developed, and to license or permit others to do so.

2. Reproduction, posting, transmission or other distribution or use of the final Contribution in whole or in part in any medium by the Contributor as permitted by this Agreement requires a citation to the Journal and an appropriate credit to Wiley-Blackwell as Publisher, and/or the Society if applicable, suitable in form and content as follows: (Title of Article, Author, Journal Title and Volume/Issue, Copyright @ [year], copyright owner as specified in the Journal). Links to the final article on Wiley-Blackwell's website are encouraged where appropriate.

\section{B. RETAINED RIGHTS}

Notwithstanding the above, the Contributor or, if applicable, the Contributor's Employer, retains all proprietary rights other than copyright, such as patent rights, in any process, procedure or article of manufacture described in the Contribution.

\section{PERMITTED USES BY CONTRIBUTOR}

1. Submitted Version. Wiley-Blackwell licenses back the following rights to the Contributor in the version of the Contribution as originally submitted for publication:

a. After publication of the final article, the right to self-archive on the Contributor's personal website or in the Contributor's institution's/employer's institutional repository or archive. This right extends to both intranets and the Internet. The Contributor may not update the submission version or replace it with the published Contribution. The version posted must contain a legend as follows: This is the pre-peer reviewed version of the following article: FULL CITE, which has been published in final form at [Link to final article].

b. The right to transmit, print and share copies with colleagues.

2. Accepted Version. Re-use of the accepted and peer-reviewed (but not final) version of the Contribution shall be by separate agreement with WileyBlackwell. Wiley-Blackwell has agreements with certain funding agencies governing reuse of this version. The details of those relationships, and other offerings allowing open web use, are set forth at the following website: http://www.wiley.com/go/funderstatement. NIH grantees should check the box at the bottom of this document.
3. Final Published Version. Wiley-Blackwell hereby licenses back to the Contributor the following rights with respect to the final published version of the Contribution:

a. Copies for colleagues. The personal right of the Contributor only to send or transmit individual copies of the final published version in any format to colleagues upon their specific request provided no fee is charged, and further-provided that there is no systematic distribution of the Contribution, e.g. posting on a listserve, website or automated delivery.

b. Re-use in other publications. The right to re-use the final Contribution or parts thereof for any publication authored or edited by the Contributor (excluding journal articles) where such re-used material constitutes less than half of the total material in such publication. In such case, any modifications should be accurately noted.

c. Teaching duties. The right to include the Contribution in teaching or training duties at the Contributor's institution/place of employment including in course packs, e-reserves, presentation at professional conferences, in-house training, or distance learning. The Contribution may not be used in seminars outside of normal teaching obligations (e.g. commercial seminars). Electronic posting of the final published version in connection with teaching/training at the Contributor's institution/place of employment is permitted subject to the implementation of reasonable access control mechanisms, such as user name and password. Posting the final published version on the open Internet is not permitted.

d. Oral presentations. The right to make oral presentations based on the Contribution.

4. Article Abstracts, Figures, Tables, Data Sets, Artwork and Selected Text (up to 250 words).

a. Contributors may re-use unmodified abstracts for any non-commercial purpose. For on-line uses of the abstracts, Wiley-Blackwell encourages but does not require linking back to the final published versions.

b. Contributors may re-use figures, tables, data sets, artwork, and selected text up to 250 words from their Contributions, provided the following conditions are met:

(i) Full and accurate credit must be given to the Contribution.

(ii) Modifications to the figures, tables and data must be noted. Otherwise, no changes may be made.

(iii) The reuse may not be made for direct commercial purposes, or for financial consideration to the Contributor.

(iv) Nothing herein shall permit dual publication in violation of journal ethical practices. 


\section{CONTRIBUTIONS OWNED BY EMPLOYER}

1. If the Contribution was written by the Contributor in the course of the Contributor's employment (as a "work-made-for-hire" in the course of employment), the Contribution is owned by the company/employer which must sign this Agreement (in addition to the Contributor's signature) in the space provided below. In such case, the company/employer hereby assigns to Wiley-Blackwell, during the full term of copyright, all copyright in and to the Contribution for the full term of copyright throughout the world as specified in paragraph A above.

2. In addition to the rights specified as retained in paragraph $B$ above and the rights granted back to the Contributor pursuant to paragraph $C$ above, WileyBlackwell hereby grants back, without charge, to such company/employer, its subsidiaries and divisions, the right to make copies of and distribute the final published Contribution internally in print format or electronically on the Company's internal network. Copies so used may not be resold or distributed externally. However the company/employer may include information and text from the Contribution as part of an information package included with software or other products offered for sale or license or included in patent applications. Posting of the final published Contribution by the institution on a public access website may only be done with Wiley-Blackwell's written permission, and payment of any applicable fee(s). Also, upon payment of Wiley-Blackwell's reprint fee, the institution may distribute print copies of the published Contribution externally.

\section{E. GOVERNMENT CONTRACTS}

In the case of a Contribution prepared under U.S. Government contract or grant, the U.S. Government may reproduce, without charge, all or portions of the Contribution and may authorize others to do so, for official U.S. Govern- ment purposes only, if the U.S. Government contract or grant so requires. (U.S Government, U.K. Government, and other government employees: see notes at end)

\section{F. COPYRIGHT NOTICE}

The Contributor and the company/employer agree that any and all copies of the final published version of the Contribution or any part thereof distributed or posted by them in print or electronic format as permitted herein will include the notice of copyright as stipulated in the Journal and a full citation to the Journal as published by Wiley-Blackwell.

\section{G. CONTRIBUTOR'S REPRESENTATIONS}

The Contributor represents that the Contribution is the Contributor's original work, all individuals identified as Contributors actually contributed to the Contribution, and all individuals who contributed are included. If the Contribution was prepared jointly, the Contributor agrees to inform the co-Contributors of the terms of this Agreement and to obtain their signature to this Agreement or their written permission to sign on their behalf. The Contribution is submitted only to this Journal and has not been published before. (If excerpts from copyrighted works owned by third parties are included, the Contributor will obtain written permission from the copyright owners for all uses as set forth in WileyBlackwell's permissions form or in the Journal's Instructions for Contributors, and show credit to the sources in the Contribution.) The Contributor also warrants that the Contribution contains no libelous or unlawful statements, does not infringe upon the rights (including without limitation the copyright, patent or trademark rights) or the privacy of others, or contain material or instructions that might cause harm or injury.

\section{CHECK ONE BOX:}

Contributor-owned work ATTACH ADDITIONAL SIGNATURE PAGES AS NECESSARY

Contributor's signature

Date

Type or print name and title

Type or print name and title

Company/Institution-owned work

(made-for-hire in the course of employment) which is an official U.S. Government publication, is called a "U.S. Government work," and is in the public domain in the United States. In such case, the employee may cross out Paragraph A. 1 but must sign (in the Contributor's signature line) and return this Agreement. If the Contribution was not prepared as part of the employee's duties or is not an official U.S. Government publication, it is not a U.S. Government work.

U.K. Government work (Crown Copyright)

Other Government work

\section{Note to U.K. Government Employees}

The rights in a Contribution prepared by an employee of a U.K. government department, agency or other Crown body as part of his/her official duties, or which is an official government publication, belong to the Crown. U.K. government authors should submit a signed declaration form together with this Agreement. The form can be obtained via http://www.opsi.gov.uk/advice/crown-copyright/copyright-guidance/ publication-of-articles-written-by-ministers-and-civil-servants.htm

Note to Non-U.S., Non-U.K. Government Employees

If your status as a government employee legally prevents you from signing this Agreement, please contact the editorial office.
NIH Grantees

\section{Note to NIH Grantees}

Pursuant to NIH mandate, Wiley-Blackwell will post the accepted version of Contributions authored by NIH grant-holders to PubMed Central upon acceptance. This accepted version will be made publicly available 12 months after publication. For further information, see www.wiley.com/go/nihmandate. 


\title{
Cytometry

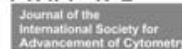

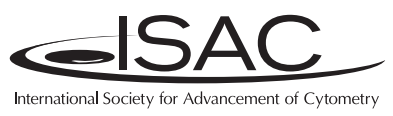

\section{À la Fizeau in Flow: Pulse Shape-Assisted Fluorescence Lifetime}

\author{
László Bene, ${ }^{1 \star}$ János Szöllősi
}

- Key terms

fluorescence lifetime; flow cytometry; phase-fluorometry; phase
FLUORESCENCE lifetime measurements are utilized more and more lately in molecular and cell biology partly due to its applicability for monitoring molecular dynamics and discrimination of molecular species, partly due to the commercial availability of microscopes and fluorimeters capable for fluorescence lifetime detection $(1,2)$. Fluorescence lifetime is the average time an excited fluorophore spends in the excited state prior to returning to the ground state, via emission of light or other, non-radiative ways of de-excitation. Its widespread utility rests on the property that in addition to fluorescence, many other processes involving the excited fluorophore may exist which take place on the same time scale and may compete with fluorescence in the de-excitation and consequently may influence fluorescence lifetime (3-5). To name a few, these processes are: internal conversion, vibrational relaxation, intersystem crossing, Förster resonance energy transfer (FRET), dynamic quenching, solvent relaxation, charge transfer, and photolysis (photobleaching); and most of these processes involve interactions of the excited fluorophore with its local environment $(1,3)$. For this reason fluorescence lifetime can be used to monitor locally the concentrations of ions and molecules, electric field and polarity, temperature, viscosity, and refractive index (1-3,6-9). By spanning a much larger range than the wavelength of the emitted fluorescence, it is more amenable for multiplexing than wavelength $(8,10)$.

'Department of Surgery, Faculty of Medicine, University of Debrecen, Debrecen, Hungary

${ }^{2}$ MTA-DE Cell Biology and Signaling Research Group, University of Debrecen, Debrecen, Hungary

${ }^{3}$ Department of Biophysics and Cell Biology, Faculty of Medicine, University of Debrecen, Debrecen, Hungary

Received 3 October 2014; Accepted 7 October 2014

Grant sponsor: TÁMOP-4.2.2.A-11/1/KONV-2012-0045 project co-financed by the European Union and the European Social Fund

Grant sponsor: OTKA NK Research Grant, Grant number: 101337
It can be used as a contrast parameter, for example, for discriminating between emitters having overlapping emission spectra (9). It is also a state parameter, meaning that it is independent of conditions of excitation such as color, intensity, and polarization of the exciting light. Based on its independence of concentration and due to the fact that it does not necessitate calibration, it is a more sensitive indicator of FRET than the intensity alone $(3,11)$. It can be changed only physically_termed radiative decay engineering-by influencing the mode structure of the random vacuum field fluctuations responsible for the stimulation of spontaneous emission, for example, by placing a metal mirror in the vicinity of the fluorophore or by embedding the fluorophore in a cavity resonator $(12,13)$.

The detection of fluorescence lifetime rests on the "drag" and attenuation imposed on the reemission process, the fluorophore acting as a low pass filter, by cutting and smoothing out sharp features of the original time variation of the exciting light (Fig. 1) (3). This feature mathematically is expressed by the operation on the time profile of excitation and pulseresponse of fluorophore-called convolution-leading to a shift to the right on the time-axis and demodulation for the time profile of fluorescence.

Instead of using short excitation pulses the fluorescence lifetime can also be measured by a long lasting observation of fluorescence, which is periodically modulated at a frequency $(\sim 100 \mathrm{MHz})$ corresponding to the inverse lifetime, with a detector the gain of which is modulated in synchrony

Grant sponsor: OTKA Bridging Fund support OSTRAT/810/213 by University of Debrecen.

Correspondence to: László Bene; Department of Biophysics and Cell Biology, Faculty of Medicine, University of Debrecen, H-4012 Debrecen P.0. Box 39, Hungary. E-mail: bene@med.unideb.hu

Published online 00 Month 2014 in Wiley Online Library (wileyonlinelibrary.com)

DOI: 10.1002/cyto.a.22583

(c) 2014 International Society for Advancement of Cytometry 


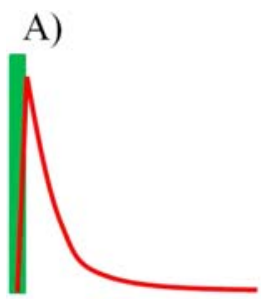

B)

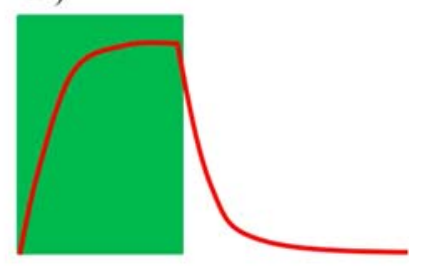

C)

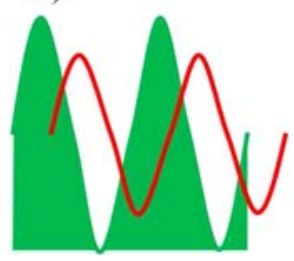

D)

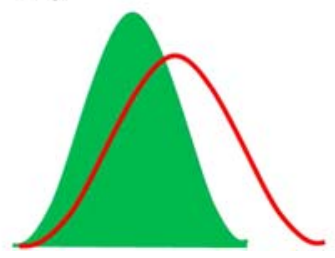

Figure 1. Illustration of the low-path filtering effect of fluorophores. The sharp features of the excitation time profiles (green shaded areas) are smoothed out by the inertia against reemission (red lines) encoded in the excited state lifetime. The different lifetime measuring techniques are based on the detection of the relative distortion of the emission profile as compared to the excitating one and to determine the characteristics of the decay profile (the different lifetimes and the relative abundance of the different lifetimes). Panel A: The fluorescence profile elicited by an excitation pulse much shorter than fluorescence lifetime (" $\delta$ pulse") is the true decay profile of fluorescence ("impulse response"). If the excitation is with not a " $\delta$-pulse" but with an extended one (Panels B-D), then the emission intensity at any given time point is determined by the contributions of all the excitations happening before that given time point, analytically described by "convolution." Panel B: Upon excitation by a square pulse, both the appearance and the disappearance of fluorescence is not instantenous, but gradual, having rates dictated by the fluorescence lifetime. Panel C: Upon excitation by a sinusoidal profile, the emission is also sinusoid, but with a phase shifted to the right and with a reduced modulation (deviation of signal amplitude from the mean). Panel D: All the information of the decay profile is kept, when the excitation is with a single pulse of Gaussian profile, such as in flow cytometry. This situation can also be handled as the first peak of the excitation with a sinusoid wave-train (Panel C). Here the peak of the fluorescence pulse is shifted to the right and its amplitude is decreased as compared to those of the light scattering (forward: FSC, perpendicular: SSC) pulses. The decay profile of the fluorescence can be obtained in the knowledge of the excitation profile, encoded in the time profile of the light scattering-forward or perpendicular-signals. However to carry out this operation requires high speed electronics to precisely fix the timing of detection of the fluorescence pulse at the rising edge of the light scattering (triggering) and large number of sampling points during approximately $10 \mu \mathrm{s}-$ pulse period. Complications can arise from, for example, photobleaching, saturation, and using light scattering as a reference of the excitation profile, because the cells are not perfect mirrors.

(homodyne detection) or almost in synchrony (heterodyne detection) with that of the excitation, but shifted in phase electronically nowadays or by translating the detector itself in older equipments, in the principle of Fizeau's measurement of

F2 speed of light (Fig. 2) $(5,7,8,10,13,14)$. As a result of the synchronous and near synchronous detections the detector signal is a DC one depending on the introduced phase step and observation time and an AC signal varying slowly $(\sim 100 \mathrm{kHz})$ at the difference frequency, respectively. However, measuring only the sample's signal is not adequate, because to take into account the retardation - that is, to fix the origin of the time of observation, which is the time of excitation-and demodulation introduced in the light path towards the detector, measurement of a sample emitting light with a known retardation in the same observation path as for fluorescence is also necessary. Scattering solution of metal powder, milk, or a light reflector mirror having zero retardance or a fluorophore of known lifetime introduced in the sample position can serve as reference. The unknown lifetime can be determined from the relative phase delay and relative demodulation of the sample as compared to the reference $(1,3-11,14)$.

The above described phase modulation method is extensively used as a contrast modality in fluorescence imaging or in bulk cuvette measurements of biological samples in lifetime spectrometers (fluorometers), where the times of observations can be substantially long to achieve high signal-to-noise ratios. Compared to these techniques, the distinguishing feature of flow cytometry is the high throughput and the multiplexing ability, two properties deserving realization of the phase method also in flow. However, in a flow cytometer, the finite duration of illumination imposes a serious constraint on the adaptation of the method. In spite of this drawback, it has been successfully used recently for discriminating between different states of fluorophores also in flow showing that the high throughput property can be advantageously combined with the phase detection. Combination of multiplexing feature of flow cytometry with the phase method-that is, to measure the lifetimes in several fluorescence channels in parallel-may be hindered by the insufficient speed of data processing electronics and the substantial cost increase (e.g., each excitation beam should be modulated independently) $(8,9)$.

To circumvent the above inconveniences of the phasemodulation method, Cao et al. (in this issue page XXX) have decided to abandon the present paradigm of lifetime measurements of using long lasting fluorescence wave-trains for obtaining lifetime information, and instead concentrate on the information content of single fluorescence pulses. Theoretically the whole information content on lifetime could be gained by considering the fluorescence response elicited by only a single excitation pulse (Fig. 1). The need for the application of the endless periodic wave-trains can be rooted back from solely practical considerations such as ensuring high signal-to-noise ratios, the adequate speed of electronics to carry out deconvolution on a single fluorescence pulse, and the convenience of using Fourier transforms in order to use the same algorithm independently of the exact shape of the exciting periodic wave (3). In spite of using a single pulse, their method, named "non-modulated fluorescence lifetime cytometry" (nFLIC), is conceptually closely connected to the phase-modulation method, because-as shown by them-it can be considered as the limiting case a periodic excitation of infinite period (or zero repetition frequency), which practically implies omitting pulses after the first one. This approach has been made feasible by the recently appearing high-speed digital data processors (e.g., 50 Mega-sample/sec DAQ having a 20 ns-sampling time necessary for $\sim 500$ data points in 
$\sim 10 \mu$ s-pulse duration, high-resolution (ns-) storing oscilloscopes) and the high-memory computers.

Although the feasibility of the single-pulse approach has been demonstrated, further challenges await for the developers both technically and theoretically, such as the elaboration of parallel in situ deconvolution of several pulses in the approximately $10 \mu$ s-pulse length. Presently the lifetime is calculated from the time delay of fluorescence pulse relative to the forward (or side) scattering pulse, defined as the period between maxima of the fitting Gaussians or the maxima or medians (halfarea points) of the signals themselves. These are rather crude parameters having also a noise and signal-shape sensitivity. The final aim would be to obtain the full fluorescence decay curve-impulse response function- per each cell by deconvoluting the fluorescence pulse shape from the exciting one
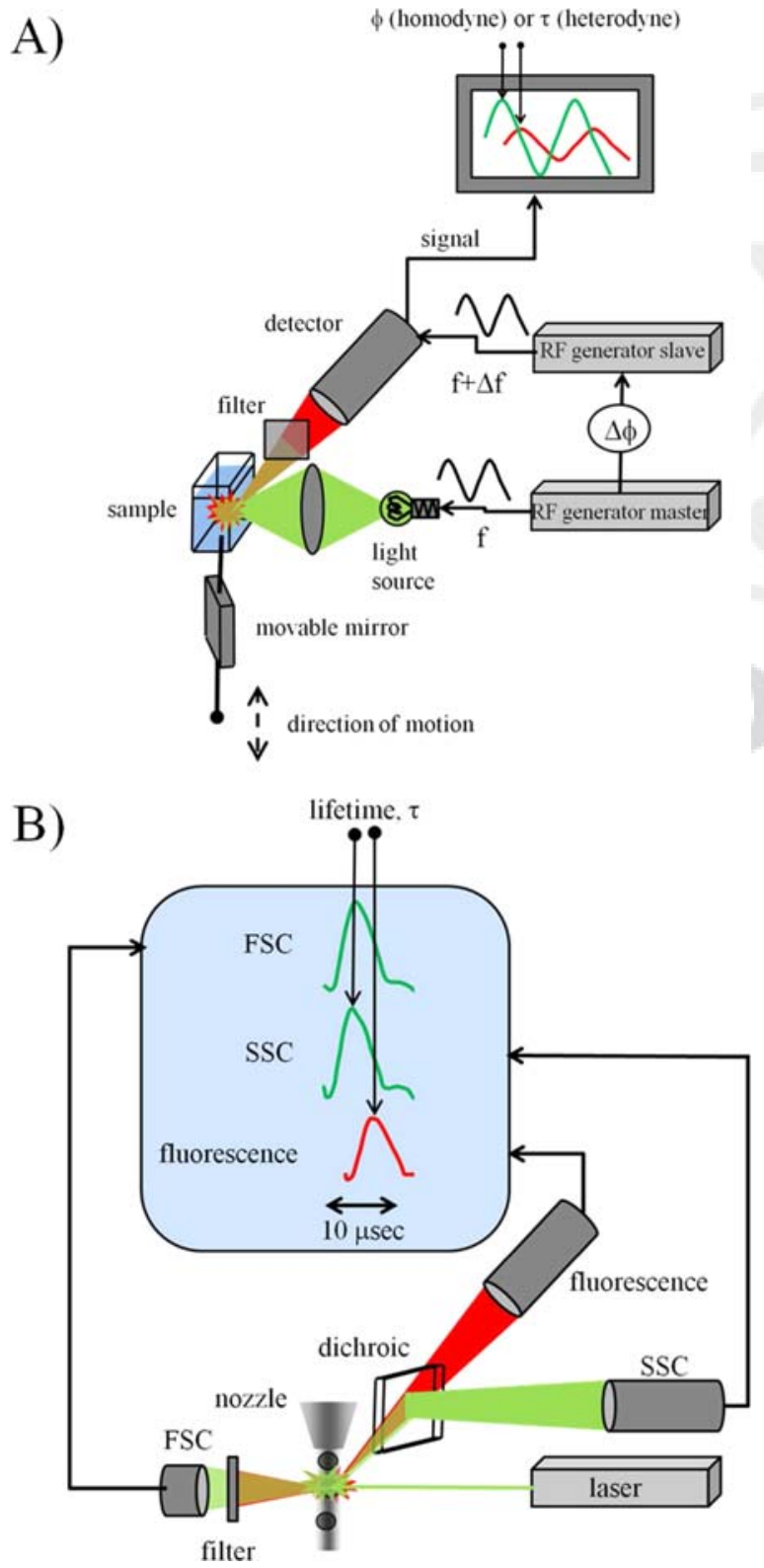

encoded in the light scattering pulse profile. Having the full decay curve for each cell the frequency distribution curves of the pre-exponentials describing the amounts of two forms of a dye, or the amounts of a dye situated in two different environments (polar-apolar, bound-unbound) can be constructed (9).

Additional complications to be solved are, for example, to handle pulse shape distortions due to improper shape of excitation profile, possible occurrence of "slit scan" mode of illumination for large cells, inhomogenous dye distribution, photobleaching, and photon-saturation, and to toggle between side and forward scatters to choose the better as a light reflector. Rotational motion of dyes could also inflate fluorescence lifetime detection, in as much as magic angle detection or excitation is used $\left(54.7^{\circ}\right.$ away from the vertical with a vertically polarized laser) (3).

Figure 2. Schemes of lifetime measurements for a general phase-modulation arrangement and for flow cytometry. Panel A: The principle of "lock-in" detection. Both the excitation and detection are modulated by the radiofrequency (RF) "master" and "slave" signal generators, either phase-locked to each other with slightly different frequencies ( $\Delta f$, heterodyne mode), or with the same frequency but with different phase steps $(\Delta \phi$, homodyne mode) between them. In each case the output of the detector is a sinusoid containing the same phase and modulation information as for the detected signal (fluorescence or scattering) $(3,5)$. At the excitation side, modulated are either the power supply of the light source (for LED, arc lamps) or its emitted light (for lasers, halogen lamps) with accusto optic modulators (AOM), Pockels-cells, earlier with Kerr-cells $(5,14)$, and even with simple mechanical shutters (Becquerel's phosphoroscope) (1,3). At the detection side, the gain of the detector (photomultiplyer gain, or image intensifier gain before CCD cameras in imaging) is modulated. These arrangements have two important aspects: (i) The first is the "lock-in" principle of detection-that is, detection in synchrony or with a fixed phase with the excitation-of short time intervals originally realized by Fizeau (Paris, 1849) in a "homodyne" experiment (14), when he measured the returning time of light via visual observation of the light source through a rotating cogs-wheel-serving as for both the "master" and "slave" signal generators-from which the determined the speed of light. (ii) The second is the need for an appropriate reference for the excitation profile, that is, an emitter having a known lifetime put precisely at the point of observation. This reference can be a solution of a dye having a known lifetime, or a reflecting mirror (e.g., in microscopes), and light scatterers such as metal powders, milk in solvents. The principle of synchronized detection is also used in other lifetime detection techniques such as time correlated single-photon counting (TSPC), time-gated fluorescence and fluorescence upconversion (10). Panel B: Flow cytometry is inherently pulsed and synchronized due to the cells' crossing the laser beam profiles and triggering. The individual pulses correspond to the first hill of the harmonic excitation-as shown in the paper of $\mathrm{Cao}$ et al. (page $\mathrm{XXX}$ )-obtainable at the limit of small lifetimes or infinitely large modulation periods (small modulation frequencies), implying correspondingly that lifetime can be obtained by simply measuring the time delay between the fluorescence and reference pulses, that is, the light scattering pulses (FSC, SSC). The time delay $(\tau)$ between the fluorescence and light scatter pulses is grossly exaggerated in Panel B as compared to the $10 \mu \mathrm{s}$-signal duration. The success depends on how the time delay is determined, the degree to which light scattering mimics the excitation profile, and how the distorting effects of photobleaching and saturation are taken into account, to name a few possible obstacles, not withstanding "trivial" technical problems concerning the required high speed for the adequate sampling and precise timing of the pulses. 
This newly elaborated method can be used for many purposes such as genotyping and sorting according to lifetime and amplitude components of decay curves, the determination of FRET from lifetimes, or even rotational motion if the lifetimes of polarized intensity components are detected.

\section{LITERATURE CITED}

1. Berezin MY, Achilefu S. Fluorescence lifetime measurements and biological imaging. Chem Rev 2010;110(5):2641-2684.

2. Akers WJ, Berezin MY, Lee H, Guo K, Almutairi A, Fréchet JMJ, Fischer GM, Daltrozzo E, Achilefu S. Biological applications of fluorescence lifetime imaging beyond microscopy. Proc SPIE 2010;7576:757612(1-9).

3. Clegg RM. Fluorescence lifetime-resolved imaging: What, why, how-a prologue. Chap. 1. In: Periasami A, Clegg RM, editors. FLIM Microscopy in Biology and Medicine. Boca Raton: Taylor \& Francis Group; 2010. pp 3-34.

4. Clegg RM. Early history of lifetime measurements and lifetime imaging, published on May 25, 2012; https://www.youtube.com/watch?v=6oTkuosPygg.

5. Verveer PJ, Hanley QS. Frequency domain FLIM theory, instrumentation, and data analysis. Chap. 2. In: Gadella TWJ, editor. FRET and FLIM Techniques. In: van der Vliet PC, Pillai S, editors. Series Laboratory Techniques in Biochemistry and Molecular Biology. Amsterdam: Elsevier; 2009. pp 61-94.
6. Cui HH, Valdez JG, Steinkamp JA, Crissman HA. Fluorescence lifetime-based discrimination and quantification of cellular DNA and RNA with phase-sensitive flow cytometry. Cytometry Part A 2003;52A:46-55.

7. Okabe K, Inada N, Gota C, Harada Y, Funatsu T, Uchiyama S. Intracellular temperature mapping with a fluorescent polymeric thermometer and fluorescence lifetime imaging microscopy. Nat Commun 2012;3:705.

8. Houston JP, Naivar MA, Freyer JP. Digital analysis and sorting of fluorescence lifetime by flow cytometry. Cytometry Part A 2010;77A:861-872.

9. Cao R, Pankayatselvan V, Houston JP. Cytometric sorting based on the fluorescence lifetime of spectrally overlaping signals. Opt Express 2013;21(12):14816-14831.

10. Groma GI, Heiner Z, Makai A, Sarlós F. Estimation of kinetic parameters from timeresolved fluorescence data: A compressed sensing approach. RSC Adv 2012;2:1148111490.

11. Deka C, Lehnert BE, Lehnert NM, Jones GM, Sklar LA, Steinkamp JA. Analysis of fluorescence lifetime and quenching of FITC-conjugated antibodies on cells by phase-sensitive flow cytometry. Cytometry Part A 1996;25:271-279.

12. Klar TA, Dulkeith E, Feldman J. Time-resolved fluorescence measurements of fluorophores close to metal nanoparticles. Chap. 8. In: Lakowicz JR, Geddes CD, editors. Radiative Decay Engineering, Vol. 8. In: Topics in Fluorescence Spectroscopy. New York: Springer; 2005. pp. 249-273.

13. Novotny L, Hecht B. Light emission and optical interactions in nanoscale environments. Chap. 8. In: Principles of Nano-Optics. Cambridge: Cambridge University Press; 2006. pp. 250-303.

14. Gaviola E. Ein Fluorometer. Apparat zur Messung von Fluoreszenzabklingungszeiten. Z Phys 1926;42:853-861. 
AQ1: Author: The original article referenced by this Commentary is actually by Cao et al., not Ruofan et al. as was used in your manuscript. The lead author's name is Ruofan Cao (Not using the Chinese structure of Lastname/Firstname). This has been changed in your manuscript's text (one instance) and in the figure 2 legend where it's also cited.

AQ2: Please note that the key words "phase-fluorometry; phase lifetime; modulation lifetime" have not been used in the text.

AQ3: Please update the page number.

AQ4: Please provide the editor name for Ref. 12.

AQ5: Author, if you want to have color figures printed in color, please inform the editor when you return materials. The cost of color printing is $\$ 500$ per page (not by the figure). There is no cost to you for online color only 